\title{
Dramatising Identity on Irish Language Television: Aifric (TG4)
}

\author{
Ruth Lysaght \\ An Foras Feasa, NUI Maynooth
}

Copyright (c) 2013 by Ruth Lysaght. This text may be archived and redistributed both in electronic form and in hard copy, provided that the author and journal are properly cited and no fee is charged for access.

\begin{abstract}
Aifric (Telegael 2006-8) a live action comedy drama series for young teenagers, gives an extra dimension to a relatively conventional entertainment genre through its use of the Irish language on screen and on set. One of the largest scale longer-term drama productions for TG4, Aifric is aimed at an audience which enjoys Australian series, British soaps and American sit coms. Significantly, viewers are addressed as members of a similar culture, who understand its norms and expectations, rather than as some pan-global 'youth audience' who exist only to be entertained. Aifric presents humorous stories about somewhat quirky characters with credible relationships. Although the language is not foregrounded as a theme in the drama, its treatment results from very conscious decisions by the programme-makers. Performed by largely native-speaking actors, there is a strong drive to present a vibrant and funny Irish-speaking world. However, for most viewers, the use of the indigenous national language on screen remains noteworthy. Telegael were sensitive to this in taking on the commission, and in choosing to create an 'Aifric universe' where Irish is fluently used by everyone, add another layer to the question of Irish language identity.
\end{abstract}

Key words: Identity, television, Irish language, drama series, production, TG4

Resumen. Aifric (Telegael 2006-8), una serie de acción real destinada a jóvenes adolescentes, aporta un aspecto novedoso al género relativamente convencional de entretenimiento de la comedia dramática gracias al uso de la lengua irlandesa en la pantalla y en el plató. Siendo una de las producciones de mayor envergadura y duración de TG4, Aifric está orientada a un público que disfruta de las series australianas, las telenovelas británicas y las comedias americanas. Significativamente, se dirige a la audiencia en tanto que miembros de una misma cultura, y por tanto partícipes de unas mismas normas y expectativas, y no como un público globalizado al que simplemente hay que entretener. Aifric presenta historias humorísticas en torno a relaciones plausibles de personajes un tanto extravagantes. Aun cuando en la serie no se hace hincapié en la lengua como tema, el tratamiento que se le otorga es el resultado de decisiones meditadas por parte de los programadores. La presencia de una mayoría de actores irlandés-parlantes revela una clara intención de presentar el mundo de habla irlandesa como vital y entretenido. No obstante, para muchos espectadores el uso de la lengua nacional nativa en la pantalla no deja de ser un hecho excepcional. La compañía Telegael era consciente de ello al acometer el proyecto y por ello, al decidir crear un "universo Aifric" en el que todo el mundo habla en irlandés con fluidez, ha añadido un nuevo matiz a la cuestión de la identidad lingüística irlandesa.

Palabras clave. Identidad, televisión, lengua irlandesa, serie de TV, producción, TG4.

Since 1996, the television station TG4 has been broadcasting to a national audience as
Gaeilge [in Irish]. With more than 100 crew and a cast of almost 150 actors, Aifric (Telegael

ISSN 1699-311X 
2006-8) a live action comedy drama series for young teenagers, was the first ever such series made in Ireland in either of the official languages. Through its use of Irish, both on screen and in production, Aifric engages with official discourses of identity, questions of globalised teen entertainment formats and contemporary attitudes to place and language.

\section{Language and Television}

Spoken fluently by a minority of people, Irish nonetheless has a significant symbolic presence as a marker of national and/or community identity (CSO, 2011). The language has official national status and is supported by the state to greater or lesser degrees of effectiveness (Ireland 1937, 2003). The launch of Teilifís na Gaeilge (now TG4) in 1996, after decades of campaigns, has led to a blossoming of the image of the language in new domains for both speakers and non-speakers.

Because the language has been supported by the state for several decades and yet is spoken only by a minority, the Irish situation is considered a "rather anomalous example of minority language broadcasting" (Cormack 2000: 394). In the early part of the twenty-first century, the Irish government took a new approach to the language, moving away from territoriality in favour of ecological and identity arguments. This ideological shift was helpful in bringing together language development agencies north and south of the border. It was at this time that Teilifís na Gaeilge (now TG4) was established.

TG4 operates in a broadcasting environment of four free-to-air channels, with English as a dominant language on three of them, and an increasing availability of digital and cable options. Since 1996, the station has been broadcasting to a national audience as Gaeilge. Whilst the primary audience has to be nativespeaking communities, part of the mandate of TG4 is to reach a national audience which includes many non-fluent speakers of Irish. This sets the station apart from most other minority language broadcasting initiatives. TG4 is a unique media phenomenon in Ireland, showcasing the cultural confidence which had been running continuously for many generations in Irish-speaking communities, unseen by majoritarian media.

Indigenous national language television has a complex role to play in supporting language and culture - a role which must take into account the sociolinguistic context of the place in which the station is broadcasting. TG4 has the goal of enhancing the status of the indigenous language and associated culture. Irish appears very different to citizens depending on their own ability/fluency, and on their sense of national and cultural identity. This means that the broadcaster has to reach out to a range of different audiences.

The appearance of the hitherto almost invisible Irish language across a growing range of media genres has contributed to a change in the image of the language for many people. Television has powerful effects on the image of a language for both speakers and non-speakers. It gives Irish a degree of "acoustic credibility" (Ó Tuathaigh 2008), when children see it as part of the contemporary world (Howell 1992: 218). For non-speakers, television demonstrates the reality of the language (Ó hIfearnáin 2000: 8 ), providing a non-threatening introduction to some aspects of the language and its associated culture and values, promoting cultural and sociolinguistic awareness. The presence of the indigenous minority language on television also has the effect of taking away some of the mystique (or associated political radicalism) which it may have had in the eyes of the majority. The 'normalisation' of the language as a taken-for-granted feature of broadcasting should render it familiar and eventually almost invisible (Scannell 1996: 153). However, nonfluent speakers still tend to focus on it.

In contrast to previous times, when the minoritised language appeared to offer little to the outsider, and many young speakers were also unconvinced about the place of their heritage in the contemporary world, the advent of innovative broadcasting explores new settings for the indigenous language, celebrating its adaptability and creativity (Lysaght \& Lysaght 2011). For fluent-speakers, this is merely the making visible of an integral part of the full range of their language practice, but for the non-fluent, this is a new and exciting thing to see. Television, as an unthreatening domestic medium, is easily accessible to people, and provides non-speakers with a new perspective on a language and culture which may hitherto have seemed to them to be a 'closed door'. 


\section{Irish identity on Screen}

Much majority film, television and literature which feature indigenous characters or a 'minority' story consists of people on the outside looking in, and we never see the alternative - people inside looking in, or indeed people on the inside looking out (Ó Cofaigh interview 2001). There is a double burden for minority language media, as there are both linguistic and cultural specificities to 'translate' to the screen. The strength of an alternative media service is in part to convey a different epistemology through similar technology, perhaps through different visual styles and attendant critiques and evaluations. The ultimate goal is to 'transform' or identify other ways of seeing and being.

Television genres are a useful starting point for an enquiry into the 'alterity' of minority language broadcasting production. When conventions and genres are borrowed and given a local twist, the question of cultural specificity becomes more urgent. Browne refers to this reliance on pre-existing formats as 'cultural dependency' (Browne 1996: 230). However, the use of established codes may well be necessary for the television 'language' to successfully reach audiences accustomed to these norms. It is also possible to produce a programme generically similar in appearance to conventional majority formats, but where the spirit (Barclay 1990; Waititi 2008) is different.

Although there has been little Irish language screen fiction to date, TG4's drama series engage with continuities and discontinuities of representations of Ireland and the Irish characters on screen for over more than a century. TG4 has been successful in the realm of drama, moving from the popular comedy series of its first years to more ambitious (and co-funded) series with darker themes. ${ }^{1}$ Various genres have developed on the channel: soap, comedy, adult drama, crime and mystery. Aifric differs in its target audience (teens) and in its mentor-like approach to production.

\section{Production Context of Aifric}

The importance afforded Aifric is shown by its prominent position in the schedule: episode

1. For a more general overview of Irish television drama, see Helena Sheehan (2004: 58-61). one of the first series was broadcast on HallowE'en 2006, the traditional start of the Celtic new year, as part of TG4's ten year anniversary celebrations. Aifric's $17 \mathrm{~h}$ slot is on the cusp between Cúla 4 (after-school programming for primary) and Síle (for an older school-age audience). Broadcast with English subtitles, it is aimed at the same people who often watch Home and Away and The OC, various British soaps and American sit coms in fact, young people with similar tastes to the cast members (Butler 2009). Paul Mercier, the director of Aifric, believes there is a requirement for indigenous drama for teenagers on Irish television to counteract material from the US:

This is not saying that The Simpsons and Friends are necessarily negative influences, but this whole notion of existence and identity as defined and created by imported television programmes has to be challenged. When you add in the Gaeltacht dimension, it is even more important to give teenagers a sense of confidence in their own language and culture (Mercier, quoted in Siggins 2005).

The portrayal of native culture on screen is subtle. Whilst the setting is recognisably Irish, there is an element of hyperrealism in the colour and preponderance of interiors. The storylines of Aifric are universal, albeit with a realistic local flavour, dealing with characters and relationships to the exclusion of broader social affairs. Tadhg Mac Dhonnagáin, cocreator of the series, notes, "We wanted it to be funny... I wasn't interested in 'issues' like teen pregnancy" (2010).

Aifric was designed to be organic, to grow with the actors and to develop talent. Continuity was achieved over the five years working on the ambitious project (three years of production), as the same core cast and crew were involved (Ní Chíosain 2012). ${ }^{2}$ The series

2. Commissioned by TG4, Aifric was funded by the Sound and Vision scheme of the BCI (Broadcasting Commission of Ireland, now the BAI), and the Regional Film and Television Fund of Bord Scannán na hEireann [the Irish Film Board], (tax incentive Section 481). Writer Tadhg Mac Dhonnagáin was approached by Micheál Ó Domhnaill (Head of Development for Telegael Media Group) to co-create and develop the series. The director, and former teacher, Paul Mercier has 
was produced by the independent production company Telegael, based in An Spidéal in the Conamara Gaeltacht, about $15 \mathrm{~km}$ from Galway city. ${ }^{3}$ At the launch of the second series, Aifric was seen to enjoy the official imprimatur of the Minister for Communications, Energy and Natural Resources, who also praised the public service quality of TG $4^{4}$ and noted the image the series presented of the Irish language:

Like TG4 itself - Aifric is young, exciting, modern and attractive yet totally inclusive, unique and true to life... In an age of globalization and fragmented markets, a popular series like this can work wonders for the Irish language - particularly among young people (Ryan 2007).

Seen as a flagship for the language and of creative fiction at TG4, not only did Aifric achieve official recognition, but it was also very popular with its target audience. Series one of Aifric was the most watched children's

written and directed theatre and television drama, and short films in Irish and English. He moved from Dublin to Galway with his family in the early 2000s, which mirrors the situation of the de Spáinn family. Other writers for the series have also written for Ros na Rún and Turas Teanga [a language-learning series for adults] inter alia (Mullin 2008). Nationwide casting sessions were held in 2004 to find new talent for the programme (Cummins 2008). After three months of auditions of over 15000 actors, those selected were brought together in Telegael for a three-week intensive training course before shooting began. The young actors began as unknowns, but are now the subject of positive comments from peers on bebo, you tube and other online fansites (e.g. "taim i ngra le maidhc...." [i'm in love with maidhc...]) (Telegael 2008).

3. Established in 1989 by RTÉ and Údarás na Gaeltachta, Telegael Media Group mostly does revoicing (in several languages, with international collaborators) and has won Emmy awards for its animation work. The success of the company demonstrates the importance of broadband and digital capacity for small-scale production houses in areas which were previously considered remote. It is built on a strong belief in abilities and competence of people from the locality.

4. "Free to air, universally available public service broadcasters are not a luxury. They are an essential component of our society and TG4, in commissioning a series like this, makes the case for Public Service Broadcasting very eloquently indeed" (Ryan 2007). programme on TG4 in 2006 and the official programme website (www.aifric.tv) received over 65,000 hits in the first week of broadcast of the series in November 2006. In late October 2008, Aifric was the 12th most watched of all TG4 programmes for teens, with a $12 \%$ share for that age group (Ní Ghríofa, 2008).

The quality of Aifric was also recognised by several awards: the IFTA (Irish Film and Television Awards) for Best Children's/Youth Programme in 2007, 2008 and 2009, the Bronze Torc at the 2008 Celtic Media Festival (Children's category), and a special mention at the Prix Circom Regional 2008, as well as awards for individual cast members. The series was also nominated in the category of Best Drama Series at the Celtic Film Festival and the TVNow Awards in 2007.

\section{Young Audience and Irish Language Identity}

So far, there is a lack of research on minority language audiences in general, and their motivations in and attitudes to accessing television in their own language. Nevertheless, from the point of view of the broadcaster, the young audience are "strategically crucial for the entire TG4 project" (Ryan 2007) for two reasons: to assure the future of the station (older Irish-speaking audiences seek out TG4, but the young need to be won over) and to ensure that the language is liberated from the past, imposed or school-based depictions common to non-native speakers.

Indeed, when it comes to youth audiences, TG4 is unusually overt about the language element of their broadcast mission:

Mar chainéal tá orainn... na bealaí is fearr a aimsiú le freastal ar riachtanais ábhair leanaí agus daoine óga agus a chinntiú ar an mbealach is fearr go mbeidh siad ag teacht $\mathrm{i}$ dtreo na Gaeilge ó aois an-óg/how best to ensure that [children and young people] will gravitate towards the language from a very young age (TG4 2008: 25).

Whilst some commentators imagined a core audience of Gaeltacht-dwellers (Ó hÉallaithe quoted in Watson 2003) for TG4, the station actually attracts a majority of viewers from outside the Gaeltacht audience (diasporic webviewers, language learners and speakers who live elsewhere) (Lysaght, 2010). ${ }^{5}$ The development of technology has enabled the 
growth of Irish language speaking networks in places which had hitherto lost linguistic continuity, and TG4 is well aware where potential audiences lie:

dar ndóigh tá pobal na Gaeltachta ann, ach seans mhaith go bhfuil daonra níos mó ag pobal na gaelscolaíochta" [of course there are the people of the Gaeltacht, but it's likely that the Irish language immersion education community has a greater population] (Ó Ciardha interview 2007).

Speaking a few years after the establishment of TG4, Aifric director Paul Mercier recognises that "if the language is going to have a future, if it's going to progress, it's going to have to break out of the fixed ... view of [being] the sole preserve of the Gaeltacht" (Mercier interview 2001).

Appealing to this young (mainly second language-speaking) audience requires a recognition of their specificity - they have a different relation to language and identity than do older generations. Dónall Ó Baoill, writing about gaelscoileanna, has commented on the different cultural values of language learners, focusing on possible implications for the language and its associated culture of a growth in language 'learners' rather than 'speakers' (Ó Baoill 1999). Time will tell whether this younger generation will maintain their enthusiasm for watching entertainment in their first official language. In any case, it seems that TG4 will be dealing with the dilemma of two audiences (native and non-native speakers) for the foreseeable future.

The question also arises as to the use or adaptation of global television formats and their interaction with constructions of local or national identity. Of course, all fiction involves an imaginative distancing, and teenage viewers (like many adults) enjoy watching drama which does not reflect their everyday setting, whilst they do appreciate characters who resemble them or who face issues which resonate with their own situation. Therefore, it is not necessarily problematic that Aifric, geared for a young Irish audience, is similar in style to popular global formats. Joshua Green has carried out a study on American teen dramas

5. This reflects the demographic make-up of the country (only around $4 \%$ of Irish speakers reside in the Gaeltacht) (CSO, 2011). on Australian television in the period 1992 to 2004, and argues that "fears about Americanisation or cultural imperialism in relation to youth culture, young people and the media are misplaced" (Green 2005). Instead, he finds that intelligent and self-aware young viewers integrate the dramas into "domestic frames of reference" (Green 2005).

Appealing to the young, drawing on international popular culture, and foregrounding the first official (but minoritised) language of the country, how does Aifric engage with issues of identity?

\section{Irish Identity on Aifric}

"When the soul of a man is born in this country there are nets flung at it to hold it back from flight. You talk to me of nationality, language, religion. I shall try to fly by those nets"

(Joyce 1916: 242).

A look at traditional Irish identity as depicted in literature and on stage and screen throughout the years reveals three strong elements which are reworked in Aifric: place, people and language. Whilst Joyce's character years earlier seeks to escape the limitations of nationality, language and religion, Mercier's Aifric rather denies these broad, externalised concepts for a more local engagement. Instead of nation, we have townland; instead of religion, we have community; and the Irish language is, perhaps most unusually of all, presented as a natural and unremarkable means of expression and communication. Whilst I examine all three elements of identity, it is this third which I find of most interest.

\section{Sense of Place and Community}

Aifric is set in the fictional western town of Leitir Lár [central hillside], where the hub of the young characters' lives lies between school, home and the café, Tigh Bhaba, in a geographical zone eerily similar to the Australian soap Home and Away (without the sunny beaches). The school features predominantly in many episodes - corridors, classrooms, gym, yard. References are made to other local schools, although we never see them. Occasionally a character will venture elsewhere (e.g. hospital), but most important events occur in Leitir Lár itself. Exterior shots are quite rare, although in series one there was a extended piece on the local beach as Aifric's 
mother spearheaded a campaign to win a blue flag (an ecological standard). As a 'blow-in' family, ${ }^{6}$ the de Spáinns are slightly different from longer-term inhabitants of Leitir Lár, although there are not any major problems of integration. Family and friends are central to each episode, with emphasis on community events and participation. In previous Irish literary and theatrical production, the 'authentic' western community was depicted as self-sufficient, and an element of this persists in Aifric, as appropriate to the comedy-drama genre, although in Leitir Lár there is full acceptance of technology and trappings of contemporary life. ${ }^{7}$ The opening sequence (just over one minute in duration) features close-ups of Aifric's singing face and mid shots of her dancing, superimposed over shots of Conamara roads and countryside, the scenery and camera moving swiftly, and weather patterns speeded up. This creates an interesting juxtaposition between the wild rugged west and the sophisticated, lip-glossed teenager, but the contrast is not depicted as problematic. Glamour belongs to these rural locations as much to as any city. ${ }^{8}$

The series follows a similar format to contemporary anglophone live-action drama for young viewers. The themes of Aifric are also consonant with this genre - relationships with friends, family and figures of authority. The characters, however, are more strongly individualised than in many of these series, and there is subtlety in the portrayal of the 'baddies'. Aifric's wacky family and sometimes fickle schoolfellows provide a web of challenges as she goes about her daily life. The teachers are laughed at as caricatures, but

6. "Blow-in" is a generally jocular, but sometimes derogatory expression for people whose forebears are not from the place in question. They often need to prove themselves in the eyes of the locals.

7. The vending machine "Súnna Tortha" in the school corridor speaks to the students as Gaeilge 'ar mhaith leat rud le nithe?' [would you like something to eat?]

8. An insistence on visual quality has long been the hallmark of TG4, in order to counteract previous negative images of the Irish language as obsolete. "Everything about the project must be of highquality and glossy" (Ryan 2007). in a gentle manner, and their human side is shown. Similarly, the most aggravating baddies (Claudia and pals) reveal a vulnerable side, so that there is no easy cartoon black and white judgement ('Spáslong'). ${ }^{9}$ Social and cultural norms are seen in the interactions between boys and girls: there is realistic shyness and restraint in the communications between Maidhc, Aifric and Ben ('Spáslong'). Also, these otherwise unstoppable characters take on a more respectful demeanour before their teachers for the most part. In the episode 'Spáslong', the consequences of illicit parties, online bullying and ill-judged kissing are treated with an intelligent lightness of touch which allows for moments of tension and regret, a depth not seen in many $\mathrm{t}(\mathrm{w})$ een dramas. The Aifric character speaks in voice-over at the end of this episode to conclude that they were all to blame for the bullying of a classmate. This emphasis on collectivity and solidarity shows an awareness of the effect of one person's actions on others, whilst reinforcing the cosiness of the teenager's interdependent social circle.

Multiple storylines mesh over what might otherwise appear to be the 'lesson', so that it is not blatant. Significantly, the viewers are addressed as members of a similar culture, who understand its norms and expectations, rather than as some pan-global 'youth audience' who exist only to be entertained. Visual and narrative humour also take the sting out of 'normal' concerns, so that teenage viewers, jaded with discussions of issues such as eating disorders and self-esteem, may laugh rather than agonise over them in the safe Aifric zone of genuine friendship. Whilst practising for a talent contest, the girls have tea in Tigh Bhaba, where the handsome Maidhc serves them chips and pizza. Sophie starts to order water, but is talked out of it by plumper Zara, who reminds her she needs more energy for dancing ('Aifric agus Zara'). In the ridiculous montage for the dance auditions sequence, we enjoy the reversal of expectation and the triumph of the underdog. After this almost slapstick sequence comes the announcement of Zara's victory, giving the lie to Aifric's belief earlier in the episode that only girls with a certain type of figure could be

9. The episodes referred to here are "Spáslong" (Tx 4.11.2008) and "Aifric agus Zara" (Tx 11.11.2008). 
successful in dancing. This entertaining sequence depicts teens coping with generic pressures albeit in a specific setting and with regard to specific cultural norms.

\section{Language}

Gaeilge Chonamara (western dialect) is the main variety of Irish used in Aifric, with a few exceptions, as some actors come from different parts of the country. ${ }^{10}$ Unlike other drama series on TG4, there is virtually no English spoken in Aifric, although there are conversational on-screen subtitles. One reason for the absence of English is that the world of Aifric is its own bubble, and not intended to reflect messy reality. Leitir Lár is a unique environment in many respects, the perfect location for Aifric's eastern family to find space to be themselves in all their alterity, and the language element is never remarked upon. ${ }^{11}$ Irish is shown as equal to expressing the vicissitudes of teenage life, and constitutes an unquestioned element thereof. Neither is there reference to English. In an interview for the English language newspaper The Irish Times, director Paul Mercier claims that:

[Aifric] doesn't have to make any excuses for the fact that it's in the Irish language because it doesn't matter what language it's in. The programme is teenage orientated... the story is coming from the kids and there's a sense that it's about them and their world - their point of view, rather than forcing something on them (Mercier 2008, quoted in Mullin 2008). ${ }^{12}$

Whilst it is true that a non-fluent-speaking audience may enjoy the programme, in fact the relation between language and storyline is

10. The main character Aifric is played by Clíona Ní Chíosain from Lucan (Dublin), whose family speak Irish at home.

11. "Ní raibh muid ag iarraidh aird ar bith a tharraingt ar an nGaeilge nó ar aon chinéal teannas idir Bearla agus Gaeilge. Go dtiocfaidh an rud sin sa mbealach ar an scéal. Ag teacht salach ar an scéal" [We didn't want to draw any attention to Irish or to any kind of tension between Irish and English. That sort of thing would distract from and interfere with the story] (Mac Dhonnagáin 2010).

12. Indeed the series is popular in other places too, and is currently broadcast in five different countries, dubbed into Breton, Spanish, Catalan and Scots Gàidhlig (Le Touze 2011). somewhat more nuanced.

The televisual world of Aifric, even without overt reference to traditional Irish language culture, is distinctly different to Englishlanguage material. As ways of speaking are linked to ways of thinking and seeing, to speak a minority language in the context of a majority genre means that the genre itself must be seen and thought of in another way. The use of the Irish language enables a new inflection on generic themes, as it creates a distancing layer between reality and the drama. In the American and Australian drama popular with this age group in Ireland, settings, lifestyles and accents differ greatly from those of the target audience, who watch for escapism. Ironically, such escapism is possible also with Aifric, because most of its audience are not fluent speakers, which means that an effect of dramatic distance is achieved. Even in Gaeltacht areas, few young people would use the language unmixed with English or in so many domains as do the onscreen characters. ${ }^{13}$ The depiction of a fullyrounded life in Irish without reference to the English language, ubiquitous in the lives of the audience, is a radical alternative to other television drama.

The way the language is used is intimately linked to the portrayal of character and to the atmosphere of the story. The scripts for the series were worked on intensively over a twoyear period by a writing team fluent in Irish and experienced in television drama. Tadhg Mac Dhonnagáin explains that the absence of English creates a different atmosphere in the 'Aifric universe'. Everyday speech in Irish is heightened to make it more dramatic, as is common in programmes scripted in any language: "tá snas breise curtha ar an gcaint lena dhéanamh spéisiúil agus drámatúil" [there is an extra 'gloss' on the dialogue to make it interesting and dramatic] (Mac Dhonnagáin 2010). With Aifric, sensitivity to dialect difference is also an integral part of the 'voice' of a character. ${ }^{14}$ Ironically, part of the realism

13. Indeed, even on set between takes, the young actors sometimes spoke to each other in English (Mac Dhonnagáin 2010; Ní Chíosáin 2012).

14. "Bhí caint na gcarachtar bunaithe ar an ngnáthchomhrá, ach rinneadh saothrú cúramach air leis na stíleanna éagsúla cainte (Conamara, BÁC) a chur in iúl, ar mhaithe le glórtha drámatúla na 
and atmosphere of the Irish language used is that some commonly-used English nouns are accepted, where to invent an Irish one would be cumbersome and draw unwanted attention to the constructed nature of the script. As Tadhg Mac Dhonnagáin remarks:

'Sleepover' a thug muid ar sleepover. Bheadh sé go hiomlán bréagach a bheith ag cumadh téarma dó - domsa, thabharfadh sé le fios gur 'drawmah Gwaylgah' a bhí idir lámha againn. [We called a 'sleepover' a 'sleepover'. It would be completely false to be inventing a term for it - to me, it would show that we were making an 'Irish language learners drama'] (Mac Dhonnagáin 2010). ${ }^{15}$

It should be noted, however, that such borrowings were not used by the writers for verbal phrases, even though this is the language practice of many young Gaeltacht people.

In contrast to other drama productions for TG4, where fluent actors ad lib or invent lines more suitable to their character, on Aifric the actors mostly stuck to the script as so much work had gone into it. ${ }^{16}$ Another unusual feature of the shoot (which took place over 13 consecutive weeks in summer to coincide with the actors' school holidays) was that the language used on set was almost exclusively Irish. This was the decision of director Mercier, who has a strong commitment to the language. Mac Dhonnagáin, who has worked on Irishlanguage television productions for over two decades, remarks, "Ní raibh sé sin feicthe agam roimhe sin agus thaitin sé go mór liom" [I had not seen that before, and I really appreciated it] (2010). For the young actors, coming from a

gcarachtar a bheith ag teacht lena ról sa scéal [The speech of the characters was based on ordinary conversation, but we worked carefully to portray the different [regional] styles of speech (Conamara, Dublin), so that the dramatic 'voices' of the characters would play a part in the story] (Mac Dhonnagáin 2010).

15. I translate Mac Dhonnagáin's term ‘drawmah Gwaylgah' as "Irish language learners drama", or a drama focusing on the language per se, using pedantic or literal translations from English without regard to naturalness.

16. Mac Dhonnagáin recalls taking advice and suggestions on occasion from the young Máirín Ní Ghaora [native-speaking actor from Carna, who played the role of Claudia's sidekick] (Mac Dhonnagáin 2010). different generation, the situation appeared normal and natural (Ní Chíosáin 2012). Ironically, because speaking Irish was not an issue for them (most being native speakers), the young actors tended to mix and switch languages easily off-camera.

\section{Conclusion}

Aifric is attractive to tweens and teens, and contributes to rendering the Irish language 'cool' as it is used as a normal means of communication in a hyper-real setting (with sets redolent of the American and Australian series familiar to this audience, such as Home and Away). It is difficult to reach this agegroup, which is one of the more demanding television audiences, distracted as they are by other leisure activities and technological devices. The high cost and high risk of live action programming for older children is often off-putting for small television stations.

Alexandra Mystra Jaffe's 'polynomic perspective' treats the relationship of linguistic form and practice to community and identity as "an emergent property of social and political life" (Jaffe 1999: 65). I read this to mean that language practice in one area may come to interact with and affect language attitudes or practice in other areas. In the case of Aifric, we see that official support of language use encourages 'natural' language use (at least in passive terms) amongst younger speakers. A nationally funded public broadcaster (TG4) commissions creative talent to create an image attractive to a youth culture which interacts freely and creatively with global models whilst retaining a local specificity in terms of storylines and setting, and most evidently in terms of language. The series Aifric depicts a world where an indigenous national language is used, and the production of the series attempted to make real such use amongst cast, crew and audiences.

Aifric presents gently humorous stories about mostly lovable and idiosyncratic characters with credible relationships. As the social concerns of teenage life centre on friends and family, their geographical isolation is rendered irrelevant. The image of the Irish language conveyed by Aifric is one of a natural means of communication amongst attractive characters. It is but one more element in their unselfconscious quirkiness, and through its distancing effect on a socio-linguistically aware audience, 
may actually make the characters more believable. Although the language itself is not foregrounded as a theme in the drama, its treatment results from a very conscious process of decision-making on the part of the programme-makers. Drawn from layered scripts with minimal English, and performed by native-speaking actors, there is a strong drive to present a vibrant and funny Irish-speaking world for the benefit of the young audience.

However, for most viewers, the use of the indigenous national language on screen remains a salient feature. A national minority language broadcaster must constantly bear in mind the complex relationship people have with their language due to historical shift and reclamation. Telegael were sensitive to this in taking on the commission, and in choosing to create an 'Aifric universe' where Irish is fluently used by everyone, add another layer to the question of Irish language identity.

\section{Works Cited}

Barclay, Barry. 1990. Our Own Image. Auckland N.Z.: Longman Paul.

Browne, Donald. 1996. Electronic media and indigenous peoples : a voice of our own? (1st ed.). Ames: Iowa State University Press.

Butler, Eoin. 2009. Interview with Clíona Ní Chiosáin: "I find it very, very difficult to relate to Aifric because she's a bit of an odd one". The Irish Times, January 1.

Cormack, Mike. 2000. "Minority Language Media in a Global Age". Mercator Media Forum, 4, 315.

CSO: Príomh-Oifig Staidrimh na hÉireann/ Central Statistics Office, Ireland. 2011. Census - CSO - Central Statistics Office Ireland. Accessed August 10, 2012, http://www.cso.ie/en/census/index.html

Green, Joshua. 2005. Acts of Translation: Young People, American Teen Dramas, and Australian Television 1992-2004 (PhD). Queensland University of Technology, Brisbane. http://eprints.qut.edu.au/16143/1/Joshua_Green_Thesis.pdf

Howell, W. 1992. "Minority-Language Broadcasting and the Continuation of Celtic Culture in Wales and Ireland”. In S. Riggins (sd.), Ethnic Minority Media, an International Perspective (p. 217242).

Ireland. 1937. Bunreacht na hÉireann / Constitution of Ireland. www.taoiseach.gov.ie/attached files/Pdf\%20files/Constitution\%200f\%20IrelandNov2004.pdf

Ireland. Acht na dTeangacha Oifigiúla/ Official Languages Act. , Pub. L. No. 32. 2003. www.irishstatutebook.ie/2003/en/act/pub/0032/index.html

Joyce, James. 1916. A Portrait of the Artist as a Young Man. New York: B.W. Huebsch.

Le Touze, Jacques-Yves. 2011. Aifric, une série irlandaise pour les ados doublée en breton. September 30. Accessed January 25, 2013, www.agencebretagnepresse.com/fetch.php?id=23326

Lysaght, Ruth. 2010. Teanga \& Tikanga: A Comparative Study of National Broadcasting in a Minority Language on Mãori Television and Teilifís na Gaeilge. PhD Thesis. University of Auckland, N.Z. http://hdl.handle.net/2292/6729

Lysaght, Ruth \& Lysaght, Rachel. 2011. "Cláracha Fáisnéise ar TG4/ Documentary Programmes on TG4". In Documentary in a Changing State: Ireland since the 1990s. Cork: Cork University Press.

Mac Dhonnagáin, Tadhg. 2010. Skype Interview - Writer. May 26

Mercier, Paul. 2001. Stiúrthóir neamhsplach/ Independent director - Personal Interview. July 5

Mullin, Angela. 2008. Director Paul Mercier on Aifric. July 10 www.iftn.ie/broadcast/?act $1=$ record\&only=1\&aid=73\&rid=4281365\&tpl=archnews \&force $=1$

Ní Chíosáin, Clíona. 2012. Aisteoir/ Actor - Personal Interview. December 7.

Ní Ghríofa, Linda. 2008. Preasráiteas/ Press release, TG4.

Ó Baoill, Dónall P. 1999. "Social cultural distance, integrational orientation and the learning of Irish". In D. Ó Baoill \& A. Chambers (eds.), Intercultural Communication and Language Learning (p. 189-200). Dublin: IRAAL (Irish Association for Applied Linguistics).

Ó Ciardha, Pádhraic. 2007. Leas Phríomh Fheidhmeannach/ Deputy Chief Executive, TG4 - Personal Interview. January 18.

Ó Cofaigh, Ciarán. 2001. Léiritheoir neamhspleách/ Independent producer ROSG - Personal Interview. June 5. 
Ó hIfearnáin, Tadhg. 2000. "Irish Language Broadcast Media: The Interaction of State Language Policy, Broadcasters and their Audiences". Current Issues in Language and Society, 7(2), 92-116.

Ó Tuathaigh, Gearóid. 2008. “The State and the Irish Language”. In C. Nic Pháidín \& S. Ó Cearnaigh (eds.), A New View of the Irish Language (26-42). Baile Átha Cliath: Cois Life.

Ryan, Eamon. 2007. Speech at the launch of TG4's Aifric 2 Series - Department of Communications, Energy and Natural Resources, October 30. Accessed January 25, 2013, www.dcenr.gov.ie/Corporate+Units/Press+Room/Speeches/2007/Launch+of+TG4s+Aifric+2+Series.htm

Scannell, Paddy. 1996. Radio, Television, and Modern Life: a phenomenological approach. Wiley-Blackwell. Sheehan, Helena. 2004. The continuing story of Irish television drama: tracking the tiger. Four Courts Press.

Siggins, Lorna. 2005. “Teen TV series as Gaeilge envisaged”. The Irish Times, July 24

Telegael. 2006-2008. Aifric. Ireland: TG4.

Telegael. 2008. "YouTube - Aifric". Accessed August 5, 2010, www.youtube.com/watch?v=OeFIUp0-R1Q

TG4. 2008. Tuarascáil Bhliantúil/ Annual Report 2008. TG4. Accessed http://tg4.ie/bearla/corp/culr.asp

Waititi, Kahurangi. 2008. "Māori documentary film: interiority and exteriority”. MAI Review, Intern Research report 6.

Watson, Iarfhlaith. 2003. Broadcasting in Irish: minority language, radio, television and identity. Dublin: Four Courts.

Received $26^{\text {th }}$ January $2013 \quad$ Last version $18^{\text {th }}$ of February 2013

Ruth Lysaght is from Ireland, and has worked in theatre, film and television as writer, script supervisor and researcher. Having completed a postdoctoral research project on Breton-language media at the Université de Bretagne Occidentale (France), she is currently a Visiting Fellow at An Foras Feasa (The Institute for Research in Irish Historical and Cultural Traditions), based in NUI Maynooth. She is also working on a book about Irish language cinema. Her interests are in language, culture and identity as seen in contemporary film and television production. 